\title{
The development of Alternaria alternata is prevented by chitinases and B-1,3- glucanases from Citrus limon seedlings
}

\author{
NORA FANTA ${ }^{1}$, XIMENA ORTEGA ${ }^{1,2}$ and LUZ M. PÉREZ ${ }^{2 *}$ \\ ${ }^{1}$ Departamento de Bioquímica y Biología Molecular, Facultad de Ciencias Químicas y Farmacéuticas, \\ Universidad de Chile, \\ ${ }^{2}$ Departamento de Ciencias Biológicas, Facultad Ciencias de la Salud, Universidad Andrés Bello. \\ República 217 - Santiago - Chile.
}

\begin{abstract}
In addition to phytoalexin synthesis, the defense response of intact Citrus limon seedlings against Alternaria alternata involves both constitutive and induced enzyme activities such as chitinases (Ch) and B-1,3-glucanases (Glu). A. alternata conidial germination was prevented by protein extracts from inoculated lemon seedlings, but also by extracts from mock-inoculated specimens. On the other hand, degradation of mycelia was accomplished only by protein extracts from inoculated seedlings. The presence of six Ch isoenzymes and of four Glu isoenzymes was detected in protein extracts from mock-inoculated seedlings. As a result of fungal inoculation, the isoenzyme pattern of $\mathrm{Ch}$ and Glu changed, making possible the detection of a new $\mathrm{Ch}$ isoenzyme and of three new Glu. Also, some constitutive $\mathrm{Ch}$ and Glu increased their enzyme activity, and those $\mathrm{Ch}$ that increased their activy also showed a broadening of their substrate specificity. These changes were prevented by $\alpha$-amanitin and cycloheximide, suggesting that the presence of new $\mathrm{Ch}$ and Glu isoenzymes was due to de novo synthesis of proteins. Results suggest that constitutive $\mathrm{Ch}$ and Glu could act as pre-formed defense molecules in Citrus limon preventing A. alternata germination, while those induced after fungal inoculation of lemon seedlings could act along with the former, to produce lysis of fungal mycelia, resulting in a more efficient control of A. alternata development..
\end{abstract}

Key terms: Alternaria alternata, lemon, hypersensitive response, Chitinases, Glucanases.

Abbreviations: $\mathrm{Ch}$ - Chitinase; Glu - $\beta-1,3$-Glucanase; HR - hypersensitive reaction; PAGE - polyacrylamide gel electrophoresis; PR - pathogenesis-related proteins.

\section{INTRODUCTION}

Alternaria alternata, which is found in the sooty molds that affect Citrus species (Pérez et al., 1991) triggers a hypersensitive reaction (HR) in lemon seedlings characterized by the induction of phenylalanine ammonia-lyase (Roco et al., 1993), synthesis of scoparone (Pérez et al., 1994a), tissue maceration (Pérez et al., 1994b), and participation of a signaling pathway that includes phosphoinositide metabolism (Ortega and Pérez, 2001), calmodulin, G-protein, and protein kinases (Ortega et al., 2002). HR has been described as one of the most effective defense mechanisms developed by plants against several pathogens where several pathogenesis-related proteins (PR) could participate and where necrosis of the tissue at the site of infection and formation of phytoalexins have been observed (Agrios, 1997). PR have been extensively studied in several systems (Collinge 1993, van Loon, 1999); those from tobacco and tomato have been classified in seven different families, mainly based on their sharing amino acid sequences, serological relationship, and biological or enzymatic activity (van Loon et al., 1994). The accumulation of PR was initially observed in the hypersentive reaction of tobacco against infection by tobacco mosaic virus and later in several herbaceous plant species (Bol et al., 1990; Bowles 1990; Woloshuck et al., 1991). Nevertheless, some constitutive enzymes with activities of some PR have been also described (Mauch et al., 1988a). Several PR

*Corresponding author: Fax: (56-2) 6618390 - e-mail: 1perez@unab.cl 
have been identified as $\beta-1,3-$ Glucanases, Glu (PR-2) and Chitinases, Ch (PR-3). Their isoelectric points, molecular weight, protein structure, subcellular localisation and function have also been determined (Kauffman et al., 1987; Kombrinck et al., 1987; Legrand et al., 1987). It has also been shown that some $\mathrm{Ch}$ have a ly sozyme activity (Majeau et al., 1990). Kasprzewska recently published a review on plant chitinases (2003), including their regulation and function. Ch have been mainly described in different herbaceous plant species, although their presence has been also reported in woody plants (Graham and Sticklen, 1994). The general role of PR has been extensively discussed by van Loon (1997, 1999). More specifically, Ch can inhibit fungal growth, a function that has been suggested on the basis of their inhibitory effect on the in vitro growth of pathogenic fungi (Mauch et al., 1988b). Ch alone (Schlumbaum et al., 1986) or in combination with B-1,3-Glu (Mauch et al., 1988a, b) can affect fungal growth. Furthermore, it has been demonstrated that transgenic plants expressing both types of enzymes are more effective in controlling fungal pathogens than those expressing only Ch genes (Cornelissen and Melchers 1993; Kim et al., 2003). Nevertheless it has been described that the expression of a $\mathrm{Ch}$ gene that contains two chitin-binding domains effectively controls fungal development (Fung et al., 2002)

Although PR such as Ch and B-1,3-Glu have been described in several herbaceous plant systems, they have not been studied in the HR developed in Citrus limon (woody) seedlings against A. alternata. Being these enzyme activities are involved in fungal cell wall degradation and in plant resistance against distinct pathogens (Kasprzewska 2003), it is important to establish whether $\mathrm{Ch}$ and/or Glu occur in lemon seedlings, and if so, whether they are related to the control of fungal development during HR. Results will allow us to understand the strategies lemon seedlings use against $A$. alternata, and how they coordinate and complement for the complete protection of the plant. The knowledge of natural plant defense systems will also allow the elaboration of strategies to improve or to acquire efficient protection mechanisms against phytopathogens.

MATERIALS AND METHODS

All chemicals used were analytical grade and purchased from Sigma and Merck.

\section{Plant Material}

Lemon seeds were obtained from ripe fruits collected from selected trees at Huertos de Betania, Mallarauco, Central Chile. They were surface sterilized with $10 \%$ sodium hypochloride for $30 \mathrm{~min}$, thoroughly washed with sterile water, heated at $50^{\circ} \mathrm{C}$ for $10 \mathrm{~min}$, cooled with sterile water to room temperature, and placed on sterile clean pleated filter paper in complete darkness at $28^{\circ} \mathrm{C}$ and $100 \%$ humidity. Once radicles reached $6-\mathrm{cm}$ length, the seedlings were transferred to an illuminated chamber $\left(128 \mathrm{~W} \mathrm{~m}^{-2}\right)$ and cultivated for two weeks with a $16 / 8$ photoperiod. These seedlings were used for all experiments.

\section{Fungal source and isolation of conidia}

A. alternata was isolated directly from sooty molds infecting Citrus trees on Potato Dextrose Agar (PDA, DIFCO) supplemented with chloramphenicol (250 $\mathrm{mg}$ per liter). It was reisolated on PDA several times until pure cultures were obtained (Pérez et al., 1991). Conidia were produced on solid Mandels medium (Mandels et al., 1974) containing $1 \mathrm{~g}$ of Citrus pectin per liter as described (Fanta et al., 1992). Conidia were obtained by carefully scraping the surface of six-dayold plate cultures as recommended by AOAC (1980).

\section{Inoculation of lemon seedling with conidia} of $\mathrm{A}$. alternata

Lemon seedlings were inoculated as in Quaas et al. (1993). Experiments were run in duplicates and repeated at least three 
times. Controls were performed with mock-inoculated seedlings. Lemon seedlings were also treated with $2 \mathrm{mg}$ per liter of $\alpha$-amanitin or with $2 \mathrm{mg}$ per liter of cycloheximide before inoculation with fungal conidia as described (Roco et al., 1993) to determine whether plant response was due to enzyme induction or enzyme activation. To establish their effect on these processes, controls were run using the same concentration of these inhibitors in tests of fungal germination and development.

Preparation of cell-free extracts and quantitation of enzyme activities

Seedlings taken at different time periods after inoculation with $A$. alternata (1-120 h) were frozen in liquid nitrogen and powdered in a cold mortar. One $\mathrm{ml}$ of 50 $\mathrm{mM} \mathrm{Na}$ acetate $\mathrm{pH} 5.0$ containing $1 \mathrm{mM}$ phenylmethylsulfonyl fluoride (PMSF) was added per $g$ of fresh tissue. Homogenates were centrifuged at $4{ }^{\circ} \mathrm{C}$ during $20 \mathrm{~min}$ at $20,000 \mathrm{x} \mathrm{g}$. Supernatants were analyzed for protein concentration (Bradford 1976) and used as the enzyme source after extensive dialysis to eliminate phytoalexins.

ExoCh, chitobiosidase and chitotriosidase activities were assayed as described (Harman et al., 1993). EndoCh and B-1,3Glu were determined as in Pan et al. (1991) and as in Trudel and Asselin (1989). A known activity of commercial $\mathrm{Ch}$ from Serratia marcescens was included in all gels as a standard to establish $\mathrm{Ch}$ activity of plant samples. Gels were scanned and analyzed using the Gel-Perfect 5.2 computational system (Bozzo, 1993). Results are the mean of at least three different experiments run in duplicates. They are expressed as nkat/mg proteins (nmoles of $\mathrm{N}$-acetylglucosamine per second per mg proteins for endoCh activity or nmoles of p-nitrophenol per second per mg proteins for exo-, chitobioand chitotriosidase activities). Spectrophotometric assay of Glu was performed using laminarin as substrate (Tuzun et al., 1989). Results are the mean of at least three different experiments run in duplicates, and are expressed as nkat/ mg proteins (nmoles of glucose equivalents per second per mg proteins). SD did not exceed $10 \%$.

Effect of cell-free extracts on germination of A. alternata

Extracts from control seedlings (mockinoculated) and from inoculated seedlings, were dialyzed twice against $100 x$ their volume of distilled water and twice against $10 \mathrm{mM}$ sodium acetate $\mathrm{pH} 5.0$ to eliminate small molecules and the phytoalexins formed at the same time period (Roco et al., 1993). Dialysis membranes retained 12,400 MM proteins. After dialysis, they were extracted for metabolite (scoparone) analysis by TLC (Pérez et al., 1994a) or were lyophilized and resuspended in the same buffer to test the effect on fungal conidia.

Conidia from A. alternata were incubated at $37^{\circ} \mathrm{C}$ in the presence of the abovementioned extracts $\left(1 \times 10^{4}\right.$ conidia per 200 $\mu \mathrm{g}$ of total proteins in a final volume of 150 $\mu \mathrm{L})$. Aliquots were taken at different time periods and seeded in Petri dishes containing PDA. Dishes were incubated at $28^{\circ} \mathrm{C}$, and germination was visually assessed and compared with controls (fungal conidia incubated in the presence of extracts from control seedlings or in presence of extraction buffer without additions). Positive controls were run using a known activity of commercial $\mathrm{Ch}$ from Serratia marcescens $(200 \mu \mathrm{g}$ protein containg 0.03 units $/ \mathrm{mg}$ ).

Effect of cell-free extracts on mycelia of A. alternata

Fungal conidia were cultivated in Petri dishes containing PDA. Once the dishes were completely covered by fungal mycelia, lemon cell-free extracts prepared as above were placed in contact with them as follows: holes $4 \mathrm{~mm}$ diameter and $2 \mathrm{~mm}$ deep were made in the agar and filled with $200 \mu \mathrm{g}$ of the total protein from the extracts. Plates were then incubated at $28^{\circ} \mathrm{C}$ and the 
appearance of clear zones around these holes was visualized.

\section{RESULTS AND DISCUSSION}

Effect of cell-free extracts from lemon seedlings on A. alternata

Protein extracts obtained from mockinoculated seedlings $(200 \mu \mathrm{g}$ total protein $)$ were depleted of secondary metabolites through dialysis, reduced in $70 \%$ the germination of fungal conidia similar to the control performed with $\mathrm{Ch}$ from $S$. marcescens (Fig. 1a). The presence of endoCh (Fig. 2) and of Glu (Fig. 3) activities was detected in these protein extracts. It therefore appears that constitutive $\mathrm{Ch}$ and Glu activities could act as one of the preformed defense proteins due to their effect on fungal germination. Therefore, their effect at initial stages of fungal infection could be important to prevent further development of the invading microorganism. Furthermore, this action on germination can be only attributed to proteins, because small molecules, which could act as pre-infectional compounds, were eliminated through dialysis, as was demonstrated through the absence of the phytoalexin scoparone in dialysed extracts (Fig. 4), and also by the fact that heated extracts did not prevent fungal germination (Fig. 1a).

Time course experiments run with intact lemon seedlings inoculated with $A$. alternata showed that endo-Ch, Chitobiosidase and ExoCh activities began to increase after 60 hours treatment (Fig. 2 ), while $3-1,3-$ Glu activity maximized at 72 hours (Fig. 3). These enzymes maintained their time zero activity in lemon seedlings treated with $\alpha$-amanitin or with cycloheximide before fungal inoculation in time course experiments. As these inhibitors did not affect conidia germination or fungal development (data not shown), it may be suggested that the increase in these enzyme activities as a result from fungal infection was due to their "de novo" synthesis. These results agree with the prevention of "de novo" synthesis of PAL and of scoparone described in the HR of
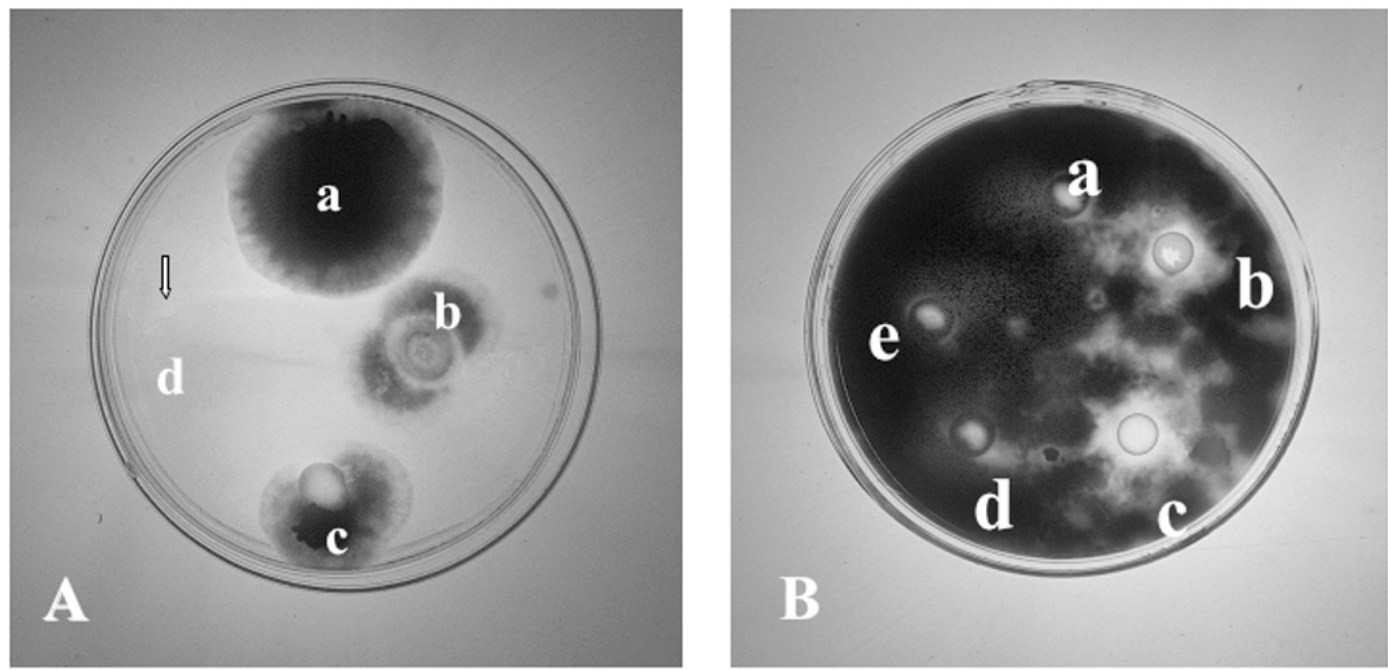

Figure 1. Effect of protein extracts from inoculated and mocked-inoculated lemon seedlings on Alternaria alternata. 1a. Germination and development of mycelia of A. alternata. Conidia suspensions $\left(10^{6} \mathrm{conidia} / \mathrm{mL}\right)$ were subjected to treatments for 72 hours. Aliquots of $20 \mu \mathrm{L}$ of treated suspensions were placed into holes in APD contained in Petri dishes. These were incubated for 5 days at $28^{\circ} \mathrm{C}$. Treatments at final concentrations: a) $10 \mathrm{mM}$ sodium acetate pH 5.0; b) $200 \mu \mathrm{g}$ of commercial chitinase from $S$. marcescens $(0.03$ units $/ \mathrm{mg})$; c) $200 \mu \mathrm{g}$ total protein of homogenates from mocked inoculated lemon seedlings, and d) $200 \mu \mathrm{g}$ total protein of homogenates from inoculated lemon seedlings. Arrow indicates site of inoculation.

1b. Degradation of mycelia from A. alternata. The fungus was grown until the entire plate was covered by mycelia. $20 \mu \mathrm{L}$ of the following treatments were placed in holes. Final concentrations indicated: a) $10 \mathrm{mM}$ sodium acetate $\mathrm{pH} 5.0$; b) $200 \mu \mathrm{g}$ of commercial chitinase from $S$. marcescens $(0.03$ units $/ \mathrm{mg})$, c) $200 \mu \mathrm{g}$ total protein of homogenates from inoculated lemon seedlings, d) $200 \mu \mathrm{g}$ total protein of homogenates from mock-inoculated lemon seedlings and e) $200 \mu \mathrm{g}$ total protein of homogenates from inoculated lemon seedlings heated for 20 minutes at $100^{\circ} \mathrm{C}$. 


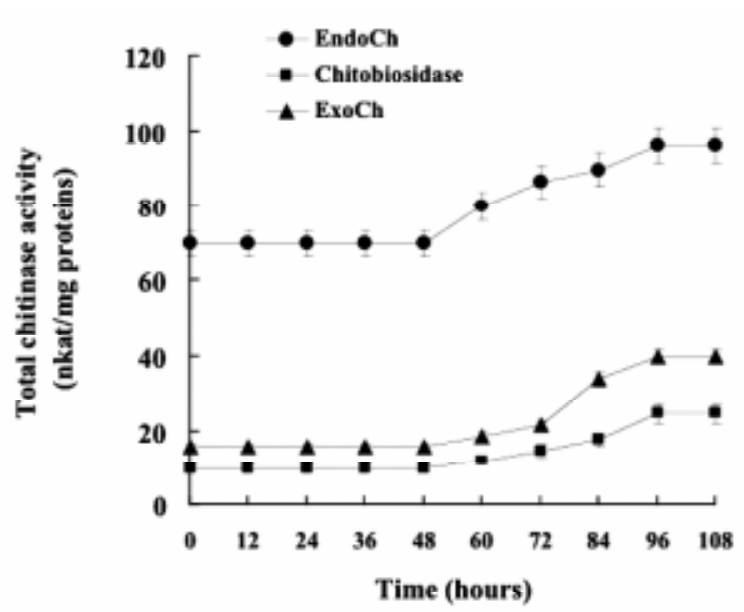

Figure 2. Time course changes in total chitinase activity in lemon seedlings after inoculation with A. alternata. EndoCh, Chitobiosidase and ExoCh maintained the time zero activity during the entire time period analyzed in lemon seedlings treated with $\alpha$-amanitin or with cycloheximide before fungal inoculation. Bars represent standard deviations.

lemon seedlings against A. alternata by these inhibitors (Pérez et al., 1994a).

Complete abolishment of fungal germination was observed when the same amount of proteins from extracts obtained after 72 hours of inoculation of lemon seedlings were tested on $A$. alternata conidia (Fig. 1a). In addition, these latter extracts showed the ability to degrade mycelia of developed $A$. alternata (Fig. 1b). To demonstrate that the antifungal activity of the inoculated extracts was only due to the proteins contained therein, heated extracts $\left(100^{\circ} \mathrm{C}\right.$ during $\left.20 \mathrm{~min}\right)$ from inoculated lemon seedlings were tested on fungal mycelia, where no degradation was observed. Similar results were obtained in treatments with buffer (Fig. 1b). Therefore $\mathrm{Ch}$ and Glu induced in lemon seedlings that develop the HR (Roco et al., 1993) could cooperate with phytoalexins to effectively control fungal germination, preventing further development or spread of the microorganism. Scoparone, the phytoalexin synthesized by lemon seedlings in response to inoculation with $A$. alternata, inhibits per se fungal growth in vitro (Pérez et al., 1994a) and appear at the same time periods where the induction of these lemon PR are observed (Pérez et al., 1994b). Thus, it can be proposed that the induction of $\mathrm{Ch}$ and Glu would reinforce the effect of phytoalexins to prevent fungal infection in this plant system, making the entire defensive response more efficient. These results are opposed to those described in Picea abines where $\mathrm{Ch}$ and $\mathrm{B}-1,3-\mathrm{Glu}$, alone or in combination, had no effect on the growth or on the morphology of hyphae from ectomycorrhizal fungi. In this case, the plant attenuates the elicitor signal allowing symbiotic interaction (Saizer et al., 1997), which is not similar to what occurs in lemon seedlings, where the plant must prevent infection by the fungus. In fact, the combination of endoCh and $\mathrm{B}-1,3$ Glu has long been proven to be very

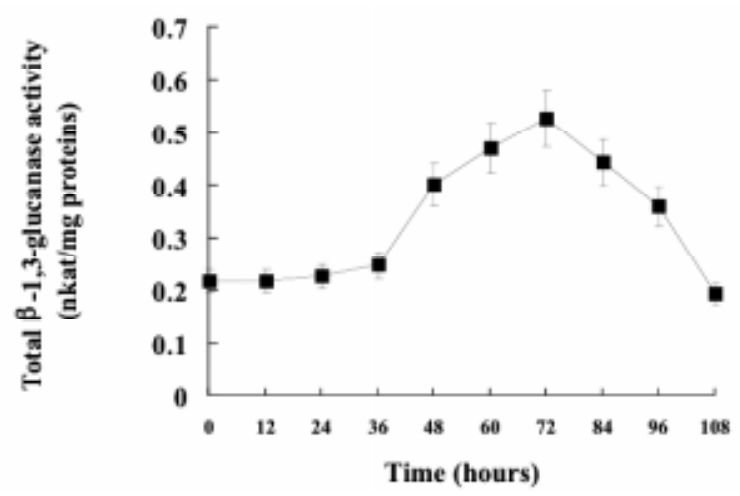

Figure 3. Time course changes in total $\beta-1,3$-glucanase activity in lemon seedlings after inoculation with A. alternata. B-1,3glucanase maintained the time zero activity during the entire time period analyzed in lemon seedlings treated with aamanitin or with cycloheximide before fungal inoculation. Bars represent standard deviations.
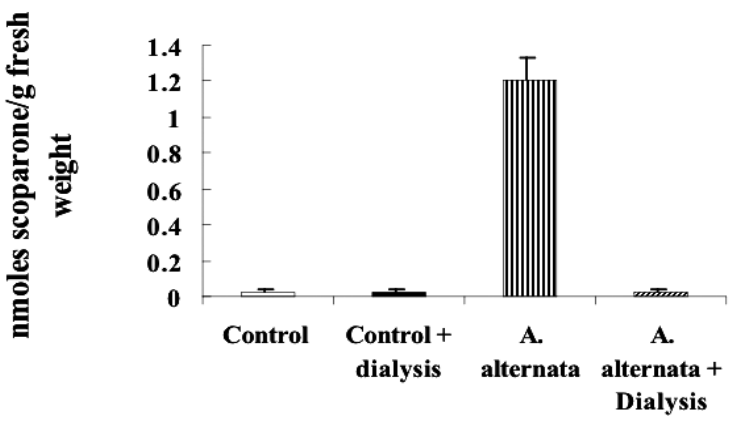

Treatment

Figure 4. Analysis of scoparone in extracts from lemon seedlings, mock-inoculated (control) and inoculated with $A$. alternata, before and after dialysis. Bars represent standard deviations. 
Chitinases (Ch) from mock-inoculated (A) and A. alternata inoculated (B) lemon seedlings: Isoelectric points and activity toward different substrates

\begin{tabular}{|c|c|c|c|c|c|}
\hline \multicolumn{6}{|l|}{ A. } \\
\hline Constitutive $\mathrm{Ch}$ & $\mathrm{pI}$ & EndoCh & \multicolumn{2}{|c|}{ Activity a (nkat/mg protein) } & ExoChitinase \\
\hline Ch1 & 7.39 & $3.3 \pm 0.4$ & n.d. & n.d. & $7.5 \pm 0.8$ \\
\hline Ch2 & 7 & $6.7 \pm 0.6$ & n.d. & n.d. & $8.2 \pm 0.7$ \\
\hline Ch3 & 6,62 & $3.5 \pm 0.3$ & n.d. & n.d. & n.d. \\
\hline Ch4 & 5,85 & $3.4 \pm 0.3$ & n.d. & n.d. & n.d. \\
\hline Ch5 & 5,72 & $26.7 \pm 2.3$ & n.d. & n.d. & n.d. \\
\hline Ch6 & 4,8 & $27.8 \pm 2.8$ & n.d. & n.d. & n.d. \\
\hline \multicolumn{6}{|l|}{ B. } \\
\hline & $\mathrm{pI}$ & EndoCh & Chitobiosidase & Chitotriosidase & ExoChitinase \\
\hline \multicolumn{6}{|c|}{ Activity ${ }^{\mathrm{a}}$ (nkat/mg protein) } \\
\hline \multicolumn{6}{|l|}{ Increased $\mathrm{Ch}$} \\
\hline Ch1 & 7.39 & $6.7 \pm 0.7$ & $3.3 \pm 0.3$ & $3.4 \pm 0.3$ & $15.3 \pm 1.4$ \\
\hline Ch2 & 7 & $12.7 \pm 1.2$ & $6.5 \pm 0.6$ & $6.7 \pm 0.7$ & $16.1 \pm 1.6$ \\
\hline \multicolumn{6}{|l|}{ Induced Ch } \\
\hline $\mathrm{Ch} 7$ & 4.5 & $6.9 \pm 0.6$ & n.d. & n.d. & n.d. \\
\hline
\end{tabular}

a Isoelectric focusing and enzyme activity were performed after 96 hours treatment n.d. not detected

effective in controlling fungal growth, as reported by Mauch et al. (1988b, Kim et al., 2003).

When the same $\mathrm{Ch}$ activity from $S$. marcescens was tested on fungal mycelia, a degradation was also observed, although its magnitude was smaller than the one produced by extracts from inoculated lemon seedlings (Fig. 1b), probably due to the fact that it did not contain B-1,3-Glu activity. The synergism between $\mathrm{Ch}$ and Glu has been reported in pea tissues infected with Fusarium solani where protein extracts, which contained high activities of Ch and $\beta-1,3-$ Glu, inhibited the growth of most of the tested fungi. In this same system, the combination of the purified enzymes was as effective as the inhibition caused by the corresponding crude protein on fungal growth. These results suggested that $\mathrm{Ch}$ and $\beta-1,3$ Glu were the main antifungal proteins in pea tissue because extracts from untreated, immature pods did not inhibit fungal growth (Mauch et al., 1988b). Therefore a similar situation could be occurring in lemon seedlings accounting for fungal control at the levels of prevention of fungal germination by constitutive $\mathrm{Ch}$ and Glu and of mycelia degradation by induced isoenzymes if development occurred. This agrees with the evidence that $\mathrm{Ch}$ and Glu can help defend plants against fungal infection (Leubner-Metzger and Meins, 1999; Kasprzewska, 2003; Kim et al., 2003). Nevertheless it cannot be discarded that other antifungal proteins in addition to Ch and Glu could be also present in extracts from inoculated or noninoculated seedlings, for example those that could be altering fungal membrane structure or permeability (Lorito et al. , 1996).

Changes in Ch and Glu activity pattern in lemon seedlings as a result of fungal inoculation with A. alternata

The analysis of number and substrate specificity of $\mathrm{Ch}$ and Glu could contribute to explain the differential behavior between extracts from mock-inoculated and inoculated lemon seedlings. The former contained six endoCh activities, accounting for $70 \mathrm{nkat} / \mathrm{mg}$ protein of total basal 
activity. They differed in their isoelectric point, data that was used to number the different isoenzymes, and in their substrate specificity (Table IA). While all isoenzymes showed endoCh activity, only $\mathrm{Ch} 1$ and $\mathrm{Ch} 2$ showed exoCh activity. This multiplicity of $\mathrm{Ch}$ is commonly found in plant tissues, where some are involved in physiological processes, while others are related to plant defense (Neuhaus, 1999). More specifically, eleven isoforms of acidic $\mathrm{Ch}$ were described in non-embryogenic $C$. sinensis callus with isoelectric points between 4.62 and 5.4. Some of them showed both $\mathrm{Ch}$ and chitosanase activities (Osswald et al., 1993, 1994). Several Ch are present in Lupinus albus in the absence of infection or stressed conditions, which are constitutively expressed in the intercellular fluids (IF), where IF-3 is a protein with $\mathrm{Ch}$ lysozyme identity found in leaves, stems, and roots (Regalado and Ricardo, 1996). Moreover, it has been possible to differentiate between $\mathrm{Ch}$ with antifungal activity, such as those present in class I and class IIb from tobacco, from those belonging to class IIa from the same plant species that are not antifungal (Neuhaus, 1999).

Inoculated lemon seedlings showed the six previously-described isoenzymes plus another named $\mathrm{Ch} 7$ (Table IB). Ch3, Ch4, $\mathrm{Ch} 5$ and $\mathrm{Ch} 6$ did not change their activity nor their substrate specificity as a result of fungal inoculation of lemon seedlings. On the other hand, an increase of endoCh and ExoCh activity for $\mathrm{Ch} 1$ and $\mathrm{Ch} 2$ was detected as well as the induction of endochitotriosidase and endochitobiosidase activities associated with these same isoenzymes. The induced $\mathrm{Ch} 7$ only showed endoCh. Therefore, endoCh activity of $\mathrm{Ch} 1$, $\mathrm{Ch} 2$ and $\mathrm{Ch} 7$ from inoculated seedlings could account for the total endoCh induction detected at 72 hours (Fig. 2). The chitobiosidase and chitotriosidase activities now detected for $\mathrm{Ch} 1$ and $\mathrm{Ch} 2$, along with the increase in endoCh and ExoCh provided by $\mathrm{Ch} 1$ and $\mathrm{Ch} 2$ and an extra endoCh from Ch7, could provide a wider spectrum of activities for full degradation of fungal chitin as was observed in Figure 1b. These changes in number and substrate

B-1,3-glucanases (Glu) from mock-inoculated (A) and A. alternata inoculated (B) lemon seedlings: isolelectric points and enzyme activity

\begin{tabular}{ccc}
\hline A. Constitutive Glu & pI & Glu activitya (pkat/mg protein) \\
\hline Glu1 & 9.1 & $60.6 \pm 5.8$ \\
Glu2 & 7.1 & $36.4 \pm 3.1$ \\
Glu3 & 6.6 & $39.4 \pm 3.2$ \\
Glu4 & 4.4 & $65.6 \pm 6.1$ \\
\hline
\end{tabular}

B.

pI Glu activitya (pkat/mg protein)

$\begin{array}{ccc}\text { Increased Glu } & & \\ \text { Glu1 } & 9.1 & 107.0 \pm 9.8 \\ \text { Glu2 } & 7.1 & 80.0 \pm 7.5 \\ \text { Induced Glu } & & 47.5 \pm 4.1 \\ \text { Glu5 } & 8.9 & 27.0 \pm 1.9 \\ \text { Glu6 } & 8.5 & 201.2 \pm 18.6 \\ \quad \text { Glu7 } & 8.3 & 37.0 \pm 2.9 \\ \text { Maintained Glu } & & \\ \quad \text { Glu3 } & 6.6 & 0 \\ \text { Suppressed Glu } & & \end{array}$

\footnotetext{
a Isoelectric focusing and enzyme activity were performed after 72 hours treatment
} 
specificities of $\mathrm{Ch}$ were not observed in lemon seedlings previously treated with $\alpha$ amanitin or with cycloheximide, suggesting that they correspond to a de novo response of the plant against A. alternata. Controls showed that these inhibitors did not affect fungal germination and development at the concentrations used, and therefore results cannot be attributed to the lack of effect of A. alternata on lemon seedlings.

On the other hand, four constitutive B$1,3-$ Glu differing in their $\mathrm{pI}$ were found in lemon seedlings. This data was used to number the different isoenzymes (Table IIA), which accounted for a total basal activity of $200 \mathrm{pkat} / \mathrm{mg}$ protein. The presence of constitutive Glu is very common as they are involved in several physiological processes such as seed germination and pollen development fertilization, etc. (Leubner-Metzger and Meins, 1999).

The ca 2.5-fold increase in total Glu activity observed at 72 hours as a result of inoculation of intact lemon seedlings with conidia of $A$. alternata (Fig. 3) could be explained because of the presence of three new basic isoenzymes named Glu5, Glu6 and Glu 7, although Glu4 was not visualised during the same time period (Table IIB). The induced Glu5 accounted for $40 \%$ of total $\beta-1,3-$ Glu activity. The changes observed in total Glu activity and in the activity pattern after isoelectric focusing were not detected in lemon seedlings treated with $\alpha$-amanitin or with cycloheximide, again suggesting that they correspond to a de novo response of the plant and not to an activation of pre-existing enzymes. These results agree with those obtained in tobacco where the presence of at least four isoforms of $\beta-1,3$ Glu accounts for the high level of enzymatic activity in tobacco mosaic virusinfected tobacco Samsun NN leaves (Kauffmann 1987). Furthermore, four endoCh have been purified from this same system during the HR against tobacco mosaic virus (Legrand 1987).

Considering the results from $\mathrm{Ch}$ and Glu activities together, we cannot leave out the possibility that the increases in activity associated with constitutive isoenzymes could be due to an increase in stability of the enzymes, as has been reported for other plant systems (Graham and Sticklen, 1994). On the other hand, the changes produced as the result of fungal inoculation both in the number of $\mathrm{Ch}$ and of Glu isoenzymes and in substrate specificity of $\mathrm{Ch}$ could account for the additional lytic activity observed on fungal mycelia by protein extracts from inoculated seedlings (Fig.1b). Nevertheless, the changes observed in lemon seedlings after fungal inoculation cannot be extrapolated to other plant systems, according to reports where several time and species-dependent responses have been described for different species. In fact, no common $\mathrm{Ch}$ patterns were observed specifically related to activity, number, or molecular characteristics of the constitutive or induced isoenzymes (Graham and Sticklen, 1994; Collinge et al., 1993). It therefore appears that every plant species shows a specific pattern of response related to $\mathrm{Ch}$ and Glu, making it impossible to derive a generalized common behavior for all species.

Trying to associate a specific $\mathrm{Ch}$ and/or Glu isoenzyme to the degradation of fungal mycelia, proteins were placed in contact with grown $A$. alternata after PAGE separation. Results showed that no degradation was observed as being associated with any of the individual activity bands, whether $\mathrm{Ch}$ or Glu, suggesting that none of the individual isoenzymes is able to degrade mycelia alone, but rather they show this lytic ability when they are all together. Therefore, we propose a concerted action of all the $\mathrm{Ch}$ and Glu isoenzymes detected in inoculated seedlings, without discarding the effect of other proteins associated to antifungal activity (Lorito et al. , 1996). We may also conclude that protein extracts from lemon seedlings inoculated with $A$. alternata depleted from small molecules and from phytoalexins formed at the same time periods (Pérez et al., 1994a) completely prevent fungal germination (Fig.1a) and degrade fungal mycelia (Fig.1b), resulting in a more effective control of A. alternata development.

Finally, knowledge of the multiple mechanisms used by plants to defend themselves from the attack of different 
microorganisms will allow to us to understand the complexity of the mechanisms activated during $\mathrm{HR}$ and the development of more strategies to control phytopathogens using one or more of the defense mechanisms used by the plant.

\section{ACKNOWLEDGEMENTS}

The present work was funded by FONDECYT projects 2950046 (PhD Thesis Nora Fanta), 1940441 and 1970532 (LMP).

\section{REFERENCES}

AGRIOS GN (1997) Plant Pathology. 4th Ed. New York: Academic Press

AOAC (1980) Official methods of analysis of the Association of Official Analytical Chemist. Whorwitz, $13^{\text {th }}$ Ed. Arlington, VA: Association of Official Analitical Chemist. P: 61

BOL JF, LINTHORST HJM, CORNELISSEN BJC (1990) Plant pathogenesis-related proteins induced by virus infection. Annu Rev Phytopathol 28: 113 - 38

BOWLES DJ (1990) Defence-related proteins in higher plants. Annu Rev Biochem 59:873 - 907

BOZZO SR (1993) Programa de computación Gel-Perfect 5.2. Manual de Instrucciones. Facultad de Medicina, Universidad de Chile

BRADFORD M (1976) A rapid and sensitive method for the quantitation of microgram quantities of proteins utilising the principle of protein dye binding. Anal Biochem 72: 248 - 54

COLLINGE DB, KRAGH KM, MIKKELSEN KN, RASMUSSEN U, VAD K (1993) Plant Chitinases. Plant J 3: 31-41

CORNELISSEN BJC, MELCHERS LS (1993) Strategies for control of fungal disease with transgenic plants. Plant Physiol 101: 709 -712

FANTA N, QUAAS A, ZULUETA P, PÉREZ LM (1992) Release of reducing sugars from Citrus seedlings, leaves and fruits. Effect of treatment with pectinase and cellulase from Alternaria and Trichoderma. Phytochem 31:3359 - 64

FUNG KL, ZHAO KJ, HE ZM, CHYE MI (2002) Tobaccoexpressed Brassica juncea chitinase BjCHI1 shows antifungal activity in vitro. Plant Mol Biol 50: 283 294

GRAHAM LS, STICKLEN MB (1994) Plant chitinases. Can J Bot 72: 1057 - 1083

HARMAN GE, HAYES CK, LORITO M, BROADWAY RM, DI PIETRO A, PETERBAUER C, TRONSMO A (1993) Chitinolytic enzymes of Trichoderma harzianum: purification of chitobiosidase and endochitinase. Phytopathol 83: 313 - 318

KASPRZEWSKA A (2003) Plant chitinases - regulation and function. Cell Mol Biol Lett. 8: 809 - 824

KAUFFMANN S, LEGRAND M, GEOFFROY P, FRITIG B (1987) Biological function of pathogenesis-related proteins: four PR proteins of tobacco have 1,3- $\beta$ glucanase activity. EMBO J 6: 3209 - 12
KIM JK, JANG IC, WU R, ZUO WN, BOSTON RS, LEE YH, AHN IP, NAHM BH (2003) Co-expression of a modified maize ribosome-inactivating protein and a rice basic chitinase in transgenic rice plants confers enhanced resistance to sheath blight. Transgenic Res 12: $475-484$

KOMBRINCK E, SCHROEDER M, HAHLBROCK K (1987) Several pathogenesis-related proteins in potato are $\beta$-1,3-endoglucanase and chitinases. Proc Natl Acad Sci USA 85: 782 - 86

LEGRAND M, KAUFFMANN S, GEOFFROY P, FRITIG B (1987) Biological function of pathogenesis- related proteins: four-tobacco pathogenesis- related proteins are chitinases. Proc Natl Acad Sci USA 84: 6750 -54

LEUBNER-METZGER G, MEINS F (1999) Functions and regulation of plant $\beta-1,3$-glucanases (PR-2), In: Pathogenesis-related proteins in plants DATTA SK, MMUTHUKRISHNAN S (eds) CRC Press. pp: 49 - 76

LORITO M, WOO SL, DAMBROSIO M, HARMAN GE, HAYER CK, KUBICEK CP, SCALA, F (1996) Synergistic interaction between cell wall degrading enzymes and membrane affecting compounds. Mol Plant-Microbe Interact 9: 206 - 213

MAJEAU N, TRUDEL J, ASSELIN A (1990) Diversity of cucumber chitinase isoforms and characterisation of the one seed basic chitinase with lysozyme activity. Plant Sci 68: 9 - 16

MANDELS M, HONTZ L, NYSTROM J (1974) Enzymatic hydrolysis of waste cellulose. Biotech and Bioeng 16: 1471-93

MAUCH F, HADWIGER LA, BOLLER T (1988) Antifungal hydrolases in pea tissue. I. Purification and characterisation of two chitinases and two ß-1,3-glucanases differentially regulated during development and in response to fungal infection. Plant Physiol 87: 325 - 33

MAUCH F, MAUCH-MANI B, BOLLER T (1988) Antifungal hydrolases in pea tissue. II. Inhibition of fungal growth by combinations of chitinase and B-1,3-glucanase. Plant Physiol 88: 936 - 42

NEUHAUS JM (1999) Plant chitinases (PR-3, PR-4, PR8, PR-11). In: SK DATTA SK, MUTTUKRISHNAN $\mathrm{S}$ (eds) Pathogenesis-related proteins in plants. CRC Press. pp: 77-105

ORTEGA X, PÉREZ LM (2001) Participation of the phosphoinositide metabolism in the hipersensitive response of Citrus limon against Alternaria alternata. Biol Res 34: 43-50

ORTEGA X, POLANCO R, CASTAÑEDA P, PÉREZ LM (2002) Signal transduction in lemon seedlings in the hipersensitive response against Alternaria alternata : participation of calmodulin, G-protein and protein kinases Biol Res 35:373-383

OSSWALD WF, SHAPIRO JP, MCDONALD RE, NIEDZ RP, MAYER RT (1993) Some citrus chitinases also possess chitosanase activities. Experientia 49: 888 - 92

OSSWALD WF, SHAPIRO JP, DOOSTDAR H, MCDONALD RE, NIEDZ RP, NAIRN J, HEARN CJ, MAYER RT (1994) Identification and characterisation of acidic hydrolases with chitinase and chitosanase activities from sweet orange callus tissue. Plant Cell Physiol 35: $811-20$

PAN SQ, YE XS, KUC J (1991) A technique for detection of chitinase, B-1,3-glucanase and protein patterns after single separation using polyacrylamide electrophoresis or isoelectrofocusing. Phytopathol 81: 970 - 974 
PÉREZ LM, METTIFOGO S, ZALDÍVAR M, MUSALEM M (1991) Sooty moulds infecting Citrus species in Chile: identification of the associated fungi and the ability to excrete plant cell wall hydrolysing enzymes. Fitopatologia 26: 28 - 38

PEREZ LM, PAVANI M, QUAAS A, ROCO, A (1994a) Umbelliferone and scoparone are synthesised by lemon seedlings in the hypersensitive response against Alternaria alternata, Trichoderma harzianum and other elicitors. Fitopatologia 29: 94 - 101

PÉREZ LM, SEELENFREUND D, GARRIDO J, ROCO A (1994b) Analysis of the morphology of Citrus limon seedlings inoculated with Trichoderma harzianum and Alternaria alternata. Fitopatologia 29: $202-206$

QUAAS A, CHIONG M, ROCO A, BRAVO R, SEELENFREUND D, PÉREZ LM (1993) Antibodies against fungal conidia and antibiotics inhibit phenylalanine ammonia-lyase activation in Citrus. J Plant Physiol 141: 393 - 97

REGALADO AP, RICARDO CPP (1996) Study of the intercellular fluid of healthy Lupinus albus organs. Plant Physiol 110: 227 - 32

ROCO A, CASTAÑEDA P, PÉREZ LM (1993) Oligosaccharides released by pectinase treatment of Citrus limon seedlings are elicitors of the plant response. Phytochem 33: $1301-06$

SAIZER P, HUBNER B, SIRRENBERG A, HAGER A (1997) Differential effect of purified spruce chitinases and beta-1,3-glucanases on the activity of elicitors from ectomycorrhizal fungi. Plant Physiol 114: 957 68
SCHULMBAUM A, MAUCH F, VÖGELI U, BOLLER T (1986) Plant chitinases are potent inhibitor of fungal growth. Nature 324:365-367

TUZUN S, RAO MN, VOGELI U, SCHARDL CL, KUC J (1989) Induced systemic resistance to blue mould: early induction and accumulation of $\beta-1,3$-glucanases, chitinases, and other pathogenesis-related proteins (b-proteins) in immunised tobacco. Phytopathol 79: $979-983$

TRUDEL J, ASSELIN A (1989) Detection of chitinase activity after polyacrylamide gel electrophoresis. Anal Biochem 178: 362 - 6

VANLOON LC, PIERPOINT WS, BOLLER T, CONEJERO V (1994) Recommendations for naming plant-pathogenesis related proteins. Plant Mol Biol Reporter 12: 245

VANLOON LC (1997) Induced resistance in plants and the role of pathogenesis-related proteins. Euro $\mathrm{J}$ of Plant Pathol 103: 753 - 765

VANLOON LC (1999) Occurrence and properties of plant pathogenesis-related proteins In: SK DATTA SK, MUTTUKRISHNAN S (eds) Pathogenesis-related proteins in plants. CRC Press

WOLOSHUCK C, MEULENHOFF J, SELA-BUURLAGE M, VANDENELZEN PJM, CORNELISSEN BJC (1991) Pathogen Induced Proteins With Inhibitory Activity Towards Phytophthora infestans. Plant Cell 3: $619-28$ 